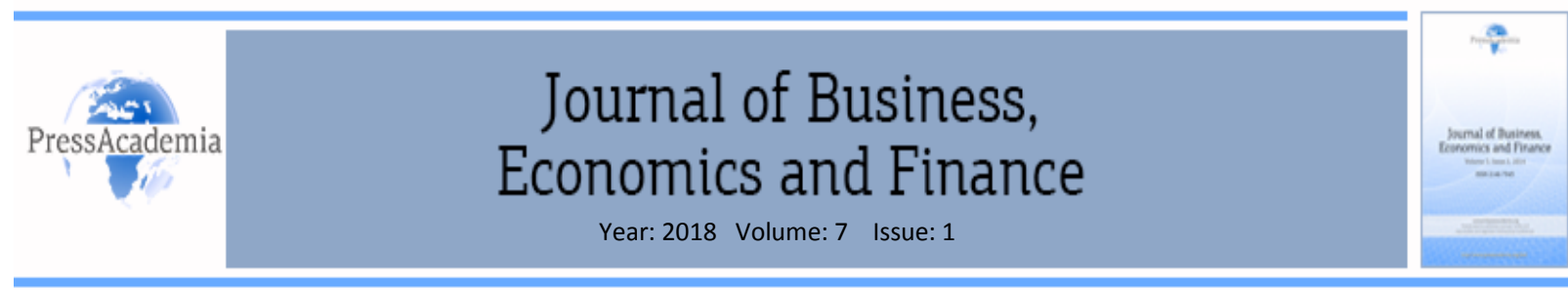

\title{
A COMPARATIVE ANALYSIS OF LOCAL GOVERNMENT FINANCIAL AUTONOMY IN ALBANIA
}

\author{
DOI: 10.17261/Pressacademia.2018.790 \\ JBEF- V.7-ISS.1-2018(1)-p.1-9
}

\section{Mariola Kapidani}

University of Tirana, Faculty of Economy, Department of Finance. Albania.

mariolakapidani@feut.edu.al, ORCID: 0000-0001-6928-6009

\section{To cite this document}

Kapidani, M. (2018). A comparative analysis of local government financial autonomy in Albania. Journal of Business, Economics and

Finance (JBEF), V.7(1), p.1-9

Permemant link to this document: http://doi.org/10.17261/Pressacademia.2018.790

Copyright: Published by PressAcademia and limited licenced re-use rights only.

\begin{abstract}
Purpose- The financial aspect of local government autonomy is considered a very important topic in the public finance literature especially for the developing countries. Fiscal autonomy empowers the local government units with the right means to provide better services for the community and to proper allocate the funds based on the citizens needs. The purpose of this paper is to study the level of financial autonomy in Albanian municipalities and compare the characteristics within different units of local government.

Methodology- In this paper we analyze the financial autonomy of Albanian municipalities by proposing an index to compare the governmental units and classify them in four classes according to the degree of autonomy. Seven quantitative indicators are used in the index, with different importance coefficients.

Findings- In Albania, while important progress has been made on advancing the decentralization reform in the last decade, autonomy of local government still remains a challenge. Local authorities do not have appropriate financial resources and they are depended on transfers from the central government budget.

Conclusion- The index results show that only a small share of local expenditures is covered by local tax revenues, while intergovernmental transfers constitute an important source of funds for the execution of local functions and service delivery.
\end{abstract}

Keywords: Local government, fiscal autonomy, intergovernmental transfers, own revenues

JEL Codes: H70, H71, H72

\section{INTRODUCTION}

Over the course of long transformations in the democratization process of the government, local government autonomy has opened important topics to discus and consider, as a core indicator of effective governance. More precisely, the financial aspect of local government autonomy is considered a very important topic in the public finance literature especially for the developing countries. Fiscal autonomy empowers the local government units with the right means to provide better services for the community and to proper allocate the funds based on the citizens needs. It is important not only to increase the effectiveness of public service allocation, but it also affects economic growth in a positive way, according to several studies (Ebel and Yilmaz, 2002). Fiscal federalism authors such as Tiebout (1956), Oates (1972), Musgrave and Musgrave (1973), argue that fiscal and administrative power delegated to local units can increase the responsiveness and the efficiency of the government. As a general argument, a government closer to the citizens is expected to accomplish better the requirements of the community. A definition given by Wolman et al. states that local autonomy is a system of local government where local government units have an important role to play in the economy and the intergovernmental system, have discretion in determining what they will do without undue constraint from high levels of government, and have the means or capacity to do so (Wolman et al., 2010: 70).

Political arguments regarding fiscal decentralization relate to the concept of local authority, which can lead to greater accountability to citizens as well as involvement of the community in defining better resource allocation policies. Since local expenditures are financed from their own incomes, citizens tend to closer monitor the local authorities. Decentralization also creates the right conditions to promote diversity and innovation in designing and implementing new approaches, in line with the current conditions of a jurisdiction (Blöchliger et al., 2006). The distinctions between economic and political 
conditions through different countries or regions require measurement and comparison of the degree of fiscal autonomy with certain generalizations and assessing the importance of local governments in terms of the public sector and its developments in time. A common way to compare and assess fiscal autonomy is the extent to which resources and responsibilities are under the control of local and regional governments (OECD, 2006). Fiscal autonomy is multi-faceted and can be assessed using several distinct indicators, as it will be analyzed further in the paper. However, the methodology and chosen indicator's importance are also related to the specific characteristics of the country's economic and institutional developments.

Decentralization in Albania took part during the transformation process toward a democratic government that occurred in all former socialist countries in the 1990s. Even though there have been significant differences in the degree of decentralization and the achieved progress, transition economies share a common trait that they began from a highly centralized system of public finances with local governments acting mainly as administrative units with little independent fiscal responsibilities (Nenkova, 2014). The macroeconomic instabilities that were present during the process created several limitations to the decentralization initiatives in transition economies. Different studies demonstrated that decentralization process in these countries was followed by delegation of greater responsibilities to local authorities in terms of service provision, but without adequate financial backing or ensuring that local government had real decisionmaking power (Olivera and Martinez-Vazquez, 2001; Rodriguez-Pose and Kroijer, 2009; Wetzel, 2001). In Albania, while important progress has been made on advancing the decentralization reform in the last decade, several challenges were faced. These challenges consisted on the high fragmentation of local authorities causing lack of capacities of the local government, as well as lack of a national policy development framework (Ministry of Finances, 2015). However, significant changes have been made in the local government autonomy legal framework, including a new territorial division and increased competences for the local units.

Local government in Albania is organized in two tiers: the first tier includes 61 municipalities as the basic unit of local government; the second tier includes 12 regions. The establishment and functioning of the local government in Albania is determined by the Constitution of Albania, the European Charter for Local Self-Government and the Law "On the Organization and Functioning of Local Government". These documents provide a clear definition of governance levels in Albania and how they function. Prior to the implementation of the Law on the New Administrative and Territorial Reform (Law No. 115, 2014), Albania was divided into 308 communes and 65 municipalities in the first level and 12 districts in the second level. Several developments are present in the intergovernmental relations too. The legal framework defines four types of transfers: shared taxes, unconditional transfer, conditional transfer for delegated functions, and conditional competitive-based investment grants from the Regional Development Fund (NALAS, 2015). However the intergovernmental finance system in Albania faces many challenges, including a high level of unpredictability of governmental transfers over the years, and frequent changes in the formula of fund allocation.

In this study we analyze the ongoing process of fiscal decentralization and the financial autonomy level of governmental units in Albania. The firs sections of the study present the theoretical framework for local government autonomy and the background of institutional changes in Albanian legal system regarding local government. A trend analysis of main indicators of local government finances in Albania is presented for the interval 2010-2016. An index of financial autonomy is modeled for the 61 municipal units of Albania, as the basic and first tier of local government. Seven quantitative indicators are used in the index, with different importance coefficients and scored from 1 to 4 according to the performance of each unit. The data used for the index is obtained from the Ministry of Finances in Albania, for the year 2016. Four classes of autonomy are created. The municipalities with higher scores are classified in class A, and those with lower level of financial autonomy in class D. The indicators included in the index are adapted for the Albanian model based in the reviewed literature and similar studies of the south European countries.

\section{LITERATURE REVIEW}

Local government autonomy is an important condition in the way a state organizes its territory and provides services to its population, by managing its resources in the most effective way (Goldsmith, 1990). The quality and quantity of public services provided in a country depends on the financial rules and incentives that govern the interactions among the various actors of the public sector (Beer-Toth, 2009). Fiscal decentralization requires that local governments must control their 'own' sources of revenue in order to reach enough financial (fiscal) autonomy and accountability to their local tax payers (Oulasvirta and Turala, 2009). In Europe the importance of financial autonomy is clearly expressed in the European Charter of Local Self-government of 1985. The Charter states in Article 9, Paragraph 3 that at least a part of the financial resources of local authorities shall derive from local taxes and charges of which, within the limits of statute, they have the power to determine the rate. The term is often used synonymously with concepts such as local fiscal discretion, decentralization, and home rule, each of which, capture different and only partially overlapping dimensions of the broader concept of local autonomy as we use the term (Wolman, 2008). 
The public sector is assigned three main roles: economic stabilization, income redistribution and allocation or public service provision (Musgrave, 1976). The first two roles are generally assigned to central government because of the competitive advantage in providing them and local attempts to address income disparities are likely to induce inefficient migration. But the allocation of public services is assigned to local government since the preferences vary among communities and jurisdictions (Dillinger, 1992; Mills, 1998). By considering this important function of local government, the fiscal autonomy has gained the interest of researchers over the years. Nevertheless the definition of the local autonomy concept is still problematic: "Local autonomy means many different things to different people" (Clark, 1984). Also, there is no agreement on the methods to measure the concept of autonomy, and the different degrees to which local government may be characterized as autonomous (Hansen and Klausen, 2002; Verhoest et al. 2004). Focusing on the financial aspects of local autonomy, two main aspects need to be addresses: the degree of income autonomy and expenditure autonomy. In a large scale, these concepts inquire the analysis of intergovernmental fiscal relations between central government and local units.

Income and expenditure autonomy are referred to as practical concepts that are more suitable for measurement purposes rather than overall financial autonomy. For instance, some types of revenue sources as earmarked grants from the central government to local governments are strictly for special expenditures on grant-eligible tasks (Oulasvirta and Turala, 2009). According to Olowu (1985) local authorities whether urban or rural, in developing countries have generally continued to rely rather too recklessly on uncertain and generally dwindling grants from the central government. Academic interest in intergovernmental fiscal relations emerged in 1950s with the article of Tiebout (1956), and the Theory of Public Finances of Musgrave (1959). Local autonomy cannot be complete unless local government units possess adequate sources of finances and the sufficient capacity and flexibility in budgeting to ensure a balance in the level or resources and spending. Income autonomy may be assessed according to the classification of income sources prepared by the OECD (2001); meanwhile the assessment of expenditure autonomy is treated differently in several studies.

The determinants of fiscal autonomy are classified in two main aspects. The first dimension involves the range and the relative importance of different functions and revenues assigned to local units, as well as the extent to which government functions are performed by the private sector. The second, more important, dimension concerns the decision-making power of sub-national governments regarding the assigned functions and revenue sources (Bahl and Linn, 1992; Molander, 2004; Stegarescu, 2005). According to Oulasvirta and Turala (2005), a systematic approach to classification, measurement and evaluation of financial autonomy may form a better basis for testing hypotheses concerning fiscal decentralization and local government autonomy in different countries. It may give some benefit for judging and comparing financial autonomy of local government levels for some normative purposes. Furthermore, it can be used as a framework aimed at supporting local governance and fiscal decentralization in developing countries.

As we mentioned earlier, there are several definitions to the concept of local autonomy, and several times different synonyms are used to refer the term. The differing treatment of local autonomy makes it difficult to generalize the indicators use for its measurements and to compare the results across authors. The level of fiscal decentralization has been commonly studied by calculating the local government share of total government expenditures and total consolidated general government revenue (Bahl, 1999; Stegarescu, 2005; Akai et al., 2007). Comparative studies orientated by the OECD framework concentrate mainly on the revenue side of fiscal decentralization and classify financial (tax) autonomy by considering the tax-raising powers of sub-central governments (Ebel and Yilmaz, 2002; Journard and Kongsrud, 2003; Meloche et al., 2004; Blöchliger and King, 2005). Main quantitative indicators used in indexing financial autonomy are: the share of own revenues in total local government revenues, the ratio of own revenues in total expenditures of local budgets and the level of self financing, share transfers and subsidies from other public budgets to local budgets, the local budget revenues per capita, the ratio of total local revenues or total local expenditure in gross domestic product, etc. However, the selection of indicators is affected by concrete characteristics of the economic and institutional development of a certain country or region.

\section{THEORY AND EVIDENCES FROM ALBANIA}

Since the collapse of socialist regime and the beginning democratization process, Albania faced many challenges in the field of local government autonomy. There have been major incentives for a successful decentralization process, not only in the financial aspect but also in the decentralization of power. The decentralization reform has progressed during 1999 and 2000, based on the Constitution (1998), the European Charter for Local Self-Government (ratified in November 1999) and the National Decentralization Strategy, adopted in 1999. The most important specific step was the approval and implementation of the Law No. 8652 of 31 July, 2000, "On the Organization and Functioning of Local Government", which sanctions the rights and authorities of the local governments units in conformity with the Constitution and the European Charter for Local Self-Government, that was followed by other laws regulating the activity of the local government and consolidating the autonomy (Ministry of Finances, 2015). Other important steps include the implementation of unconditional transfer system for the local government budgets, adopted in the State Budget Law in 2001, and further 
developed with the fiscal reform package adopted in 2002, increasing the autonomy of local government units to generate revenues from local taxes and fees. Since 2005, municipalities are responsible for the water and sewage service, as part of granting the right to administrate and develop public assets of local government.

Even though progress was achieved in these years, fiscal autonomy of local government still remains a challenge. Local authorities do not have appropriate financial resources and they are depended on transfers from the central government budget. According to the Ministry of Finances, for 2012 the state budged funded over $80 \%$ of the budget for $60 \%$ of the local government units. In terms of fiscal decentralization indicators, Albania is below other countries of Southeast Europe. Over the past decade, Albanian local governments have received less revenue as a share of GDP and of total public revenue than all their counterparts in South East Europe. This share fell from a high of 3.2\% of GDP in pre-crisis 2008 to $2.5 \%$ in 2015, and is still below the level in 2006 (NALAS, 2016). Local governments also receive the lowest share of total public revenues in the region, which in 2015 fell to a record low of 9.3\%. Overall, the national policies on the small business tax and the infrastructure impact tax have had adverse consequences on local government budgets (NALAS, 2016).

Looking closer at the progress of local government revenues in Albania, in 2016 the total revenues of local government increased by $15.5 \%$ compared to 2015 . Meanwhile there is a slightly decreasing trend of total revenues in 2011,2012 , and 2012. As a percentage, $24 \%$ of total revenues in 2016 come from local sources such as local taxes and fees, which also represent the average share for the last six years. Meanwhile, $63 \%$ of the total revenues in 2016 come from the state budget in the form of conditional and unconditional transfer. In $2014,67 \%$ of local budgets were financed by the central government. This numbers show the high dependency of local government units on the state budget transfers, considering also the low capacities for borrowing or other sources of self funding. Another consideration to take into account is the lack of predictability of state budget transfers, since the formula of fund allocation is not consistent in years and it changes with the implementation of the budget law every year.

\section{Graph 1: Local Government Revenues Trend, 2010-2016}

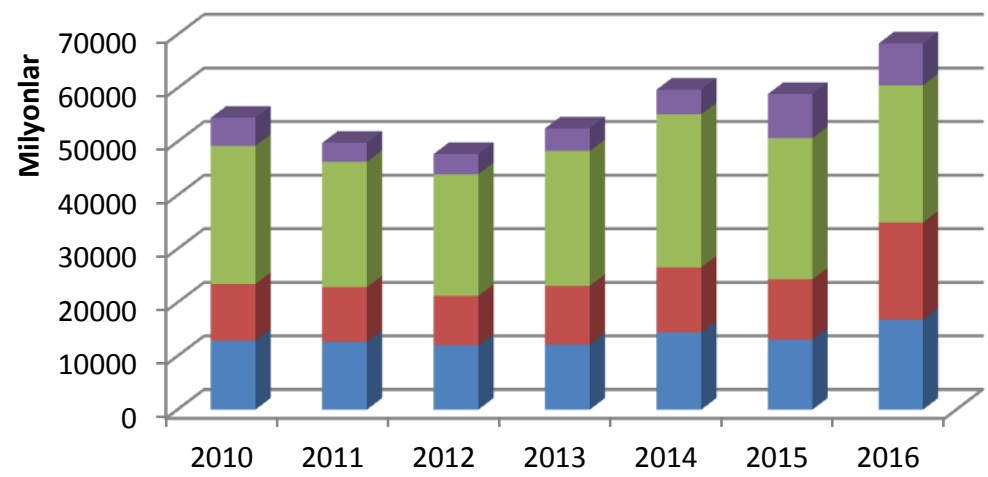

Other Revenues and Development Fund Conditional Transfer

- Unconditional Transfer

- Local Revenues

Source: Ministry of Finances, Albania

The differences between 2014 and 2016 are presented in graph 2. As it is visualized in the graph, the dependency on central government grants was much higher in 2014, where $47 \%$ of local revenues were transferred as conditional grants from the state budget, while $20 \%$ were unconditional transfers, and $7 \%$ were grants allocated from the Development Fund, still a source of central government. In 2010 the Regional Development Fund was established in charge with management of conditional grants. Initially the competitive grants were used for financing the local infrastructure projects such as road, water and waste water, but in 2010 it also included projects related with the infrastructure of the shared functions such as education, health, and culture. However, according to the Ministry of Finances "The financial mechanism of conditional transfers including the Regional Development Fund needs to be revised with the aim of applying new models in the framework of regional and local development policies and should be based on some performance criteria and eligibility to obtain funds through this grant mechanism." 


\section{Graph 2: Range of Local Government Revenues in 2016 and 2014}

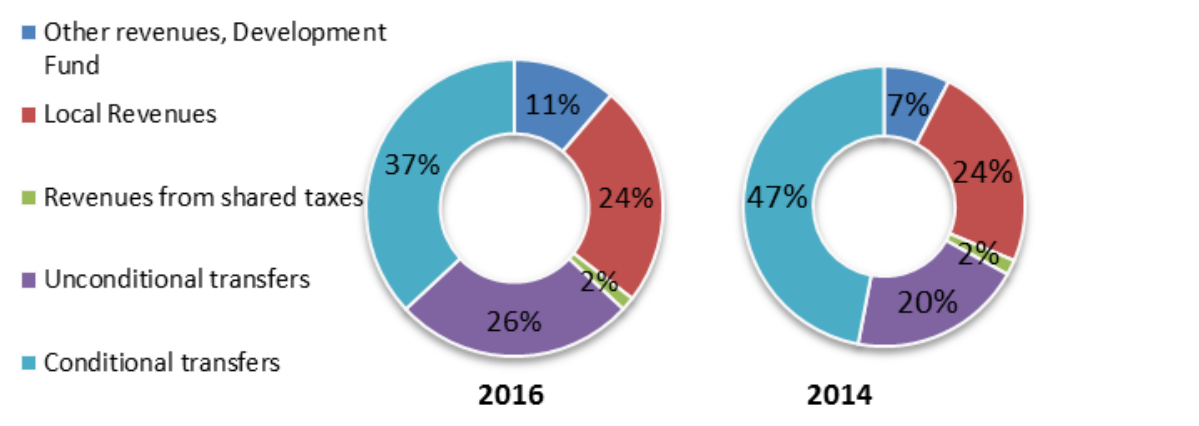

Source: Ministry of Finances, Albania

As part of setting up the policy development framework for decentralization, in July 2014 the Territorial and Administrative Reform was implemented, decreasing the number of local government units from 373 very fragmented communes and municipalities to 61 consolidated municipalities. Another important incentive was the ratification of Law on Local SelfGovernance (2015), enhancing the capacities and rights of local government units with regard to income autonomy and expenditure allocation. However, according to the Ministry of Finances (2015) "elected structures of local governance have been incapable of governing with efficiency and transparency and of involving citizens in their decision-making. In general, local governance has been closed and failed to organize and engage communities. Lack of local government units' accountability on spending of local budgets has led to failing trust among citizens and businesses, therefore, to the decline of revenues from local taxes and fees."

Considering the expenditure trend of local government units in Albania, in 2016 there is a $16 \%$ increase in total local government expenditure. For the same year $44 \%$ of the total expenditures are allocated for investment purposes. Taking a closer look at the local expenditures as a percentage of total local government revenues, for the six year trend 2010-2016 the main allocation of revenues is for currant expenditure purposes. In 2016, more than $70 \%$ of local revenues are used for short term usage. Meanwhile in 2012, the highest result is noticed, where $77 \%$ of expenditures are used for currant expenses. When considering capital expenses, only $29 \%$ of revenues of 2016 were used for capital purposes. Meanwhile the trend is increasing from 2012, where $22 \%$ of revenues were allocated for capital expenditures. Results are shown in graph number 3, with data from Ministry of Finances. Another matter to consider is the stock of local debt. Local borrowing in Albania is very low, rating from $0.02 \%$ of national debt stock in 2010 to $0.08 \%$ in 2016 . However, since 2013, the limitation on public borrowing to $60 \%$ of GDP is not in force and there is no limit on the public debt borrowing by the central government.

\section{Graph 3: Capital Expenditure and Currant Expenditure as Percentage of Local Revenues}

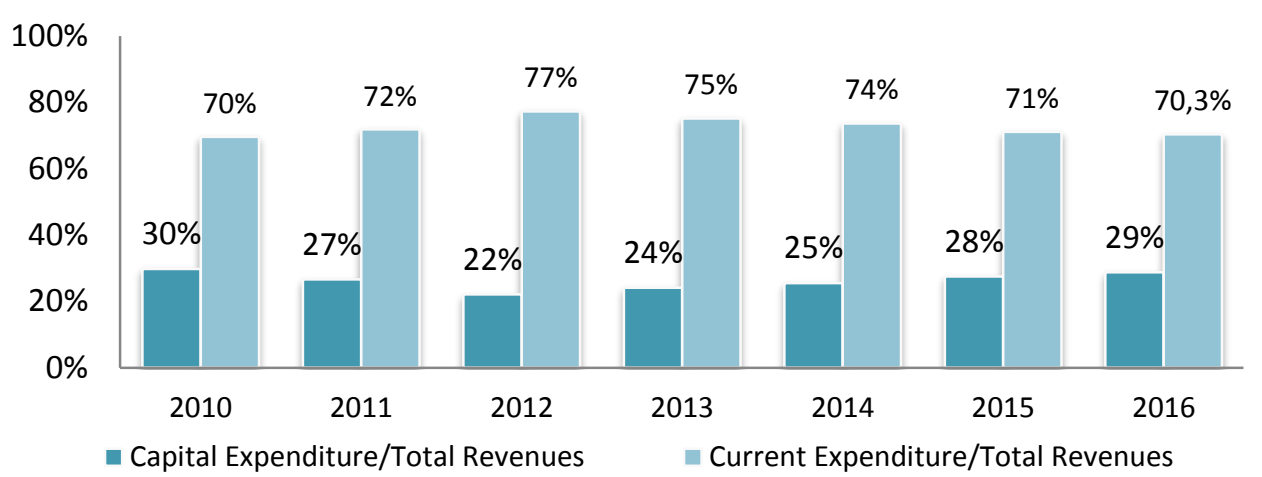

Source: Ministry of Finances, Albania 


\section{DATA AND METHODOLOGY}

After reviewing the general background of Albanian financial local autonomy reforms and developments in the last decades, we go further with the analysis in proposing a methodology that allows us to make comparisons between the municipal units in Albania. By studying the previous literature on the subject of local government financial autonomy, we have modeled an index with seven quantitative indicators, as a measurement scale of degree of autonomy. The study of Cigu and Oprea (2012) for the EU countries was taken into consideration for the index adaption, and several authors as mentioned in the literature review section. The chosen population for the study consists of 61 municipalities of Albanian Republic, with statistics for the year 2016. The index shows data on the level of each indicator performance for the total population, as well as the classification of municipalities in financial autonomy classes. The source for the analyzed data was Ministry of Finances in Albania, with further procession of the information from the author.

Each indicator is given an importance coefficient (I), based on the significance on autonomy degree. The indicators that are considered more significant to the autonomy level, according to the previous literature studies, are measured with 0.2 and the less significant with 0.1 . The total index value for the importance coefficient is 1 . On the other side, scores from 1 to 4 are given to municipalities according to the level of autonomy they reach for each indicator. As an example, those municipalities that generate more than $81 \%$ of revenues from their local sources are considered more autonomous, and as a result they get a score of 4 . Municipalities that are dependent on central government funds, as presented by the indicator of state budget transfers to total revenues for a level higher than $81 \%$, are scored with 1 . The total value of index for each of the municipalities creates further space for classification of local government units into classes of autonomy.

Table 1: Index Structure for the Local Government Fiscal Autonomy

\begin{tabular}{|c|c|c|c|c|c|}
\hline & \multirow{2}{*}{ I coefficient } & \multicolumn{4}{|c|}{ Valuation } \\
\hline & & $V=4$ & $V=3$ & $V=2$ & $V=1$ \\
\hline Own revenues/Total revenues & 0.2 & $>81 \%$ & $51 \%-80 \%$ & $21 \%-50 \%$ & $<20 \%$ \\
\hline $\begin{array}{l}\text { Transfers from state budget/Total } \\
\text { revenues }\end{array}$ & 0.2 & $<20 \%$ & $21 \%-50 \%$ & $51 \%-80 \%$ & $>81 \%$ \\
\hline $\begin{array}{l}\text { Unconditional transfer/Total } \\
\text { transfers }\end{array}$ & 0.1 & $>81 \%$ & $51 \%-80 \%$ & $21 \%-50 \%$ & $<20 \%$ \\
\hline Hunter coefficient & 0.2 & $0.71-1$ & $0.51-0.7$ & $0.21-0.5$ & $0-0.2$ \\
\hline Tax revenues/Total expenditures & 0.1 & $>51 \%$ & $31 \%-50 \%$ & $21 \%-30 \%$ & $>20 \%$ \\
\hline Shared taxes/Total tax revenues & 0.1 & $<5 \%$ & $6 \%-10 \%$ & $11 \%-20 \%$ & $>21 \%$ \\
\hline Share of local borrowing & 0.1 & $>25 \%$ & $20 \%-25 \%$ & $10 \%-19 \%$ & $<9 \%$ \\
\hline
\end{tabular}

The most important indicators of financial autonomy are: the share of own revenues to the total revenues level, and the level of state budget transfers to the total revenues of local government. These two indicators show the dependency of local budgets on the central government, and the capacity of a municipality to generate its own revenues from own sources. Another important indicator, the Hunter coefficient, includes the analysis of local expenditure coverage by state budget transfers. The total score for each indicator (V) is than multiplied by the importance coefficient (I).

\section{FINDINGS AND DISCUSSIONS}

The results are classified in four classes according to the total scores, as shown in table 2. Class A is considered the higher level of financial autonomy and class $D$ is considered lowest level of financial autonomy. For practical reasons only the municipalities with the highest scores for each class are presented and visualized in this subsection.

The results of the index are briefly presented in the table below, for each class of autonomy five representatives with the highest points are shown. In class A, large municipalities such as Tirana, Fier and Durrës have the highest level of autonomy. Himara municipality has scored 2.9 even though it is a much smaller municipality considering the number of inhabitant. In Himara municipality $34.7 \%$ of the revenues come from local taxes and fees whereas $37.1 \%$ of the total revenues come from intergovernmental transfers. Whereas in municipalities like Bulqizë $94 \%$ of local revenues come from the state budget. This 
percentage shows the very high dependency of Bulqizë municipality on central government funds. In class B, important municipalities that are also centers of regions (qark) are included. Elbasan, Berat and Vlorë show neutral levels of autonomy. Elbasan has a score of 2.3, the highest score in the class B compared with other units in this interval.

Table 2: Classification of Municipalities in Autonomy Classes

\begin{tabular}{|l|c|l|}
\hline Classes & Index Values & Municipalities \\
\hline A & $>2.40$ & Tiranë, Fier, Durrës, Korçë, Himarë \\
\hline B & $2.00-2.30$ & Elbasan, Berat, Vlorë, Përmet, Gjirokastër \\
\hline C & $1.60-1.90$ & Lezhë, Librazhd, Shkodër, Kukës, Tepelenë \\
\hline D & $1.00-1.50$ & Pogradec, Peqin, Bulqizë, Përrenjas, Maliq \\
\hline
\end{tabular}

In class $C$, municipalities show lower levels of autonomy with main representatives such as municipality of Lezha and Librazhd. Municipality of Shkodra, a large and important governmental unit of northern Albania is classified in class $\mathrm{C}$, with a score of 1.6. Shkodra has a high dependency on state budget, with $77 \%$ of the revenues generated from the central government. Only $12 \%$ of the local expenditures are supported by tax revenues of the municipality. Class $D$ represents the lowest score of financial autonomy, with municipalities of Pogradec, Peqin, Bukqizë, etc. High dependency of these municipalities on the central government is also a result of low levels of private and industry sector in these regions, as well as lack of capacities for income generation. In Memaliaj municipality, as an example of this class, the share of own revenues from local taxes and tariffs is only $6.6 \%$ of the total revenues for budget year 2016 .

Table 3: General Results for Each Indicator of Autonomy

\begin{tabular}{|c|c|c|c|c|c|c|}
\hline $\begin{array}{c}\text { Own Revenues } \\
\text { /Total Revenues }\end{array}$ & $\begin{array}{c}\text { State budget } \\
\text { transfers/Tota } \\
\text { I revenues }\end{array}$ & $\begin{array}{c}\text { Unconditional } \\
\text { transfer/Total } \\
\text { transfers }\end{array}$ & $\begin{array}{c}\text { Hunter } \\
\text { Coefficient }\end{array}$ & $\begin{array}{c}\text { Tax } \\
\text { revenues/Total } \\
\text { expenditure }\end{array}$ & $\begin{array}{c}\text { Shared taxes } \\
\text { /Tax } \\
\text { revenues }\end{array}$ & $\begin{array}{c}\text { Local } \\
\text { Borrowing }\end{array}$ \\
\hline 63 & 74 & 102 & 72 & 51 & 135 & 54 \\
\hline
\end{tabular}

When analyzing each indicator for the total of 61 municipalities, the lowest score is attained in the level of local taxes as a percentage of total local expenditures. As it results from the study, local government units are still dependent of state budget transfers and their capacity to generate revenues by local taxes is at low levels compared to other countries of the South East Europe region. The index results show that only a small share of local expenditures is covered by local tax revenues, while intergovernmental transfers constitute an important source of funds for the execution of local functions and service delivery. Another component to consider is the level of local debt, as argued in the study, most of the municipalities do not use debt instruments for funding purpose. This is considered a limitation of local autonomy, making municipalities more dependent on central government funds. However, the legal framework has progressively changed since 2009 when local borrowing process was legally and practically initiated. On the other hand, the structure of intergovernmental transfers has a higher result, which means that the level of unconditional funds is equilibrated in comparison with conditional funds. Further studies should analyze the intergovernmental transfer formula transformations and the fund fluctuations, as an important argument resulted from previous literature studies.

\section{CONCLUSION}

In this paper we have analyzed the ongoing process of fiscal decentralization and the financial autonomy level of governmental units in Albania. Fiscal autonomy empowers the local government units with the right means to provide better services for the community and to proper allocate the funds based on the citizens needs. Since the collapse of socialist regime and the beginning democratization process, Albania faced many challenges in the field of local government autonomy. Several legislation changes were present in the process of local government decentralization, as well as a new administrative and territorial reform. This transitional process was also affected by central government initiatives to decentralize its power in local units, which faced several challenges with regards to high fragmentation of local territorial units and lower economic capacities for development. However, as it results from the study, local government units in Albania are still dependent of state budget transfers and their capacity to generate revenues by local taxes is at low levels compared to other countries of the South East Europe region. After reviewing the general background of Albanian financial local autonomy reforms and developments in the last decades, in this paper we have proceeded with the analysis in 
proposing a methodology that allows us to make comparisons between the municipal units in Albania. By the classification of local government units in four classes of autonomy, the lowest score is reached in the level of local taxes as a percentage of total local expenditures. The index results show that intergovernmental transfers constitute an important source of funds for the execution of local functions and service delivery. As it is argued, high dependency of municipalities on the central government is also as a result of low levels of private and industry sector in these regions, as well as lack of capacities for income generation.

\section{REFERENCES}

Akai, N., Nishimura, Y. and Sakata, M. (2007). Complimentarily, Fiscal Decentralization and Economic Growth. Economics of Governance 8: 339-62.

Bahl, R. (1999). Fiscal Decentralization as Development Policy. Public Budgeting and Finance Summer: 59-75.

Bahl, R. and Linn, J. F. (1992). Urban Public Finance in Developing Countries. New York: Oxford University Press.

Beer-Tóth, K. (2009). Local Financial Autonomy in Theory and Practice. The Impact of Fiscal Decentralization in Hungary, Fribourg: University of Fribourg.

Blöchliger, H. and King, D. (2005). Fiscal Autonomy of Sub-central Governments. OECD Network on Fiscal Relations across Levels of Government. Paris: OECD.

Cigu, E. and Opera, F. (2012). Method of Determining the Degree of Autonomy of the Administrative-Territorial Units. Journal of Public Administration, Finance and Law.

Clark, G. L. (1984). A Theory of Local Autonomy. In: Annals of the Association of American Geographers, 74 (2), $195-208$.

Council of Europe. (2005). Explanatory Report of European Charter of Local Self-Government (ETS No. 122); http://conventions.coe.int/treaty/en/Reports/Html/122.htm, retrieved 22 September 2005.

Council of Europe. (1985). European Charter of Local Self-government. European Treaty Series No.122, Strasbourg.

Council of Europe. (2000). Effects on the Financial Autonomy of Local and Regional Authorities Resulting from the Limits set at European Level on National Debt. Local and Regional Authorities in Europe, No. 71.

Dillinger, D. (1992) Urban Property Tax Reform Guidelines and Recommendations, UMP paper 1, The World Bank, Washington, D.C.

Ebel, R. D. and Yilmaz, S. (2002). On the Measurement and Impact of Fiscal Decentralization. Policy Research Working Paper 2809, Washington D. C., The World Bank.

Goldsmith, M. (1990). Local Autonomy: Theory and Practice. In: KING, Desmond S. and Pierre, Jon (eds). Challenges to Local Government. London: Sage, 15-36.

Hansen, T. and Klausen, J. E. (2002). Between the Welfare State and Local government Autonomy. In: Local government Studies, 28 (4), 4766.

Journard, I. and Kongsrud, P. M. (2003). Fiscal Relations across Government Levels. OECD Economic Studies, No. 36, 2003/1. Paris: OECD.

Law no. 8652, dated 31 July 2000 "On organization and functioning of local governance", as amended, and Law no. 8653 , dated 31 July 2000. On administrative-territorial division of local government units.

Ligji Nr.115/2014, Për ndarjen administrativo-territoriale të njësive të qeverisjes vendore në Republikën e Shqipërisë.

Meloche, J. P., Vaillancourt, F. and Yilmaz, S. (2004). Decentralization or Fiscal Autonomy? What Does Really Matter? Effects on Growth and Public Sector Size in European Transition Countries. World Bank Policy Research Working Paper No. 3254. World Bank.

Mills, E. S. (1998). Is Land Taxation Practical? Illinois Real Estate Letter, Published by the Office of Real Estate Research, University of Illinois at Urbana Champaign.

Ministria e Financave, Republika e Shqipërisë. (2015). Strategjia Ndërsektoriale për Decentralizimin dhe Qeverisjen Vendore 2015 - 2020.

Ministria e Financave, Republika e Shqipërisë. (2016). Raporti i Monitorimit të Strategjisë për Decentralizimin dhe Qeverisjen Vendore 2015-2020.

Molander, P. (2004). Introduction, Problems of Multi-level Democracies, in P. Molander (ed.) Fiscal Federalism in Unitary States, pp. 1-8. Boston/Dordrecht/New York/London: Kluwer Academic Publishers.

Musgrave, R. A. (1959). The theory of public finance: a study in public economy. McGraw-Hill, New York.

Musgrave, R. A. (1976). Optimal Taxation, Equitable Taxation and Second-Best Taxation. Journal of Public Economic 6, 3-16. 
Musgrave, R. A. and Musgrave, P. B. (1973). Public Finance in Theory and Practice. Tokyo: McGraw-Hill Kogakusha.

NALAS, (2015). Report: Fiscal Decentralization Indicators for South-East Europe, 2006-2014. Network of Associations of Local Authorities of South East Europe (NALAS).

Nenkova, P. (2014). Fiscal Decentralization and Local Finance Reforms in Bulgaria: A Review of Ten Years' Experience, Mediterranean Journal of Social Sciences, 5(23), pp. 342-352. doi:10.5901/mjss.2014.v5n23p342.

Network of Associations of Local Authorities of South-East Europe NALAS (2016), Fiscal Decentralization Indicators for South-East Europe: 2006-2014.

Oates, W. E. (1972). Fiscal Federalism. New York: Harcourt Brace Jovanovich.

OECD, (2001). Fiscal Design across Levels of Government, Year 2000 Surveys Summary Note. OECD, Directorate for Financial, Fiscal and Enterprise Affairs. Paris: OECD.

OECD, (2006). Network on Fiscal Relations across Levels of Government. Fiscal Autonomy of Sub-Central Governments. Working Paper no. 2.

Oliveira, J. and Martinez-Vazquez, J. (2001). Czech Republic: Intergovernmental fiscal relations in the transition. World Bank: Washington. http://dx.doi.org/10.1596/0-8213-5043.

Olowu, D. (1985). Prospects of the property rates as an additional revenue source for Nigerian local governments. Quarterly Journal of Administration, OAU. Ile-Ife. P. 305-322.

Oulasvirta, L. and Turala, M. (2009). Financial autonomy and consistency of central government policy towards local governments. International Review of Administrative Sciences, Vol. 75 (2), pp. 311-332.

Oulasvirta, L. and Turala, M. (2005). Measuring the Financial Autonomy of Local Governments with a Local Autonomy Index. Glasgow Caledonian University, Caledonian Business School, Working Paper No. 40, November.

Rodriguez-Pose, A. and Kroijer, A. (2009). Fiscal Decentralization and Economic Growth in Central and Eastern Europe. Growth and Change, 40 (3):387-417.

Stegarescu, D. (2005). Public Sector Decentralisation: Measurement Concepts and Recent International Trends, Fiscal Studies 26(3): 30133.

Tiebout, Ch. (1956). A Pure Theory of Local Expenditures, Journal of Political Economy 64(5): 416-24.

Verhoest, K., Peters, G. B., Bouckaert, G. and Verschuere, B. (2004). The study of organizational autonomy: a conceptual review. In: Public Administration and Development, 24 (2), 101-118.

Wetzel, D. (2002). Decentralization in the Transition Economies: Challenges and the Road Ahead. Washington, DC: World Bank.

Wolman, H., McManmon, R., Bell, M. and Brunori, D. (2010). Comparing Local Government Autonomy across States. In The Property Tax and Local Autonomy, The Lincoln Institute. 